Japan. J. Med. Sci. Biol., 27, 205-213, 1974

\title{
A SEROEPIDEMIOLOGICAL STUDY OF HERPES SIMPLEX VIRUS
}

\author{
RYO HONDO \\ Department of Virus Infection, the Institute of Medical Science, the \\ University of Tokyo, Minato-ku, Tokyo 108, Japan
}

(Received: January 12, 1974)

\begin{abstract}
SUMMARY : Neutralizing and complement-fixing antibodies against herpes simplex virus in sera of 466 persons covering various age groups collected in 1969 were first examined. The general pattern of distribution of neutralizing antibody among children and adults older than 30 years was similar to that previously reported by Yoshino et al. (1962) with sera collected in 1959 to 1960 . A significant difference from the earlier survey was that the age group of 20 to 30 years showed various levels of neutralizing antibody in contrast to the earlier data in which a similar antibody distribution was seen between 10 and 20 years. The quantitative relation between neutralizing and complement-fixing antibodies of the above age group also resembled that of younger age groups. Further confirmation of this change was made with additional 51 serum samples collected in 1973 from adults aged between 20 and 30 years. Comparison of the present data with the earlier survey was justified by demonstrating that the methods used for detection of neutralizing antibody were almost equal in sensitivity. These results suggest that primary and repeated infections before the age of 30 years are more frequent than before and it is only after this age that persistent infection is established in the majority of population.
\end{abstract}

\section{INTRODUCTION}

A serological survey for antibodies against herpes simplex virus among normal individuals was performed by Yoshino et al. (1962) about 10 years ago, and ever since no survey of a similar scale has been carried out. In view of the experience of Burnet (1954) that a marked reduction in the antibody-positive ratio occurred in Australia during a ten-year period from 1940 to 1950, it was thought worthy to compare the present status of antibody distribution with the earlier one.

Another factor which prompted the present work was the recent increase in number of adult patients suffering from serious herpetic infections (Shoji and Hondo, 1971; Söltz-Szöts and Fanta, 1971; Rappel, 1972; Ross, 1972; Sarubbi et al., 1973), suggesting a shift of the ages at which primary infection of this virus occurs. Thus, elucidation of two points were aimed at in this study. One was whether the antibody distribution pattern among general people resembled or differed from what was previously observed and the other up to what age the parallelism between neutralizing and complement-fixing antibodies was held, which must be indicative of freshly produced antibodies.

本藤 良 (東京大学医科学研究所 ウイルス感染研究部 港区白金台 4-6-1) 


\section{MATERIALS AND METHODS}

Sera: The serum samples obtained in 1969 were sent to this laboratory for diagnostic purposes from several hospitals in Tokyo and vicinity. Sera of patients suspected of herpetic infections were excluded from the present analyses regardless of whether or not they eventually turned out to contain herpes antibodies. Sera collected in 1973 were those of personnel working in hospitals in Tokyo and vicinity. On reception, the samples were stored at $-20 \mathrm{C}$ in a deep freezer, and inactivated by heating at $56 \mathrm{C}$ for $30 \mathrm{~min}$ just prior to test. A hyperimmune rabbit serum was obtained by repeated iv inoculations of a rabbit with HeLa cell-adapted HF strain of herpes virus, and stored and inactivated as above.

Neutralization test: A modified plaque pattern method previously described (Hondo and Yoshino, 1972) was performed. An egg-adapted line of HF strain, type 1 , was used for preparation of the seed virus suspension which was a $20 \%$ emulsion of infected chorioallantois in buffered saline at $\mathrm{pH}$ 7.2. In one case, where sensitivities of two methods were compared, the test using one-day eggs was performed in exactly the same manner as described by Yoshino et al. (1962).

Complement-fixation test: Kolmer's method was used with minor modifications. The antigen was prepared from human embryonic fibroblasts infected with Takaichi strain of herpes virus, type 1 ; a cell suspension was treated in a sonic oscillator at $20 \mathrm{kc}$ for $1 \mathrm{~min}$ and centrifuged at $3,000 \mathrm{rpm}$ for $15 \mathrm{~min}$ to let the supernatant fluid serve as the antigen. The diluent used was physiological saline containing an appropriate amount of magnesium salt. In the test proper, $0.1 \mathrm{ml}$ of each serum dilution plus $0.1 \mathrm{ml}$ of antigen representing 4 units was added with $0.2 \mathrm{ml}$ of complement representing 2 units. After an overnight incubation at $4 \mathrm{C}$, the mixtures were given $0.2 \mathrm{ml}$ of a hemolytic system consisting of equal parts of a $3 \%$ suspension of washed sheep erythrocytes and a dilution of hemolysin representing 3 units, and placed in a $37 \mathrm{C}$ water-bath. Reading was done when the 1-unit complement control showed complete hemolysis. Fixation of complement as evidenced by 0 to $25 \%$ hemolysis was taken as positive.

\section{RESULTS}

\section{Distribution of Antibodies among Various Age Groups}

Individual titers of neutralizing and complement-fixing antibodies in 466 serum samples collected in 1969 are plotted against ages in Figs. 1 and 2, respectively. As to neutralizing antibody, a low titer of antibody, which may have been of maternal origin, was discerned in some babies during a half-year period following birth. The positive rate decreased after this stage and sustained a similar level up to the age of 5 years. From 5 to 10 years, still many were negative, and after this age antibody increase seemed to begin.

A point of importance was that the antibody distribution in the age group of 20-30 years did not follow the all-or-none type as it used to about 10 years ago, but showed various levels of antibody including negative titers. Thus, the antibody distribution of the groups of 10-20 and 20-30 years were essentially similar, being different from both the younger and older groups. The older groups, especially those older than 40 years, revealed a pattern approximate to the all-or-none type distrib- 


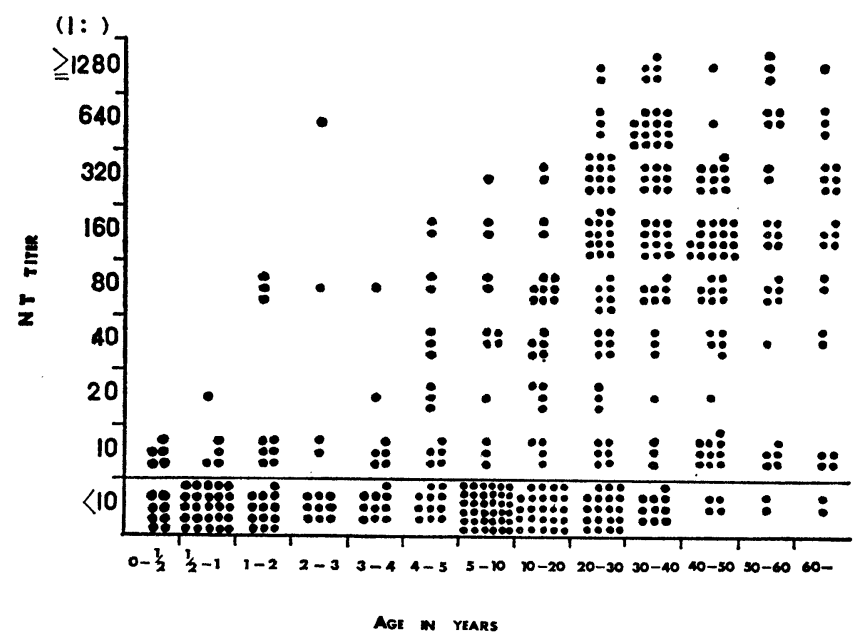

Fig. 1. Age distribution of neutralizing (NT) antibody against herpes simplexivirus among normal individuals.

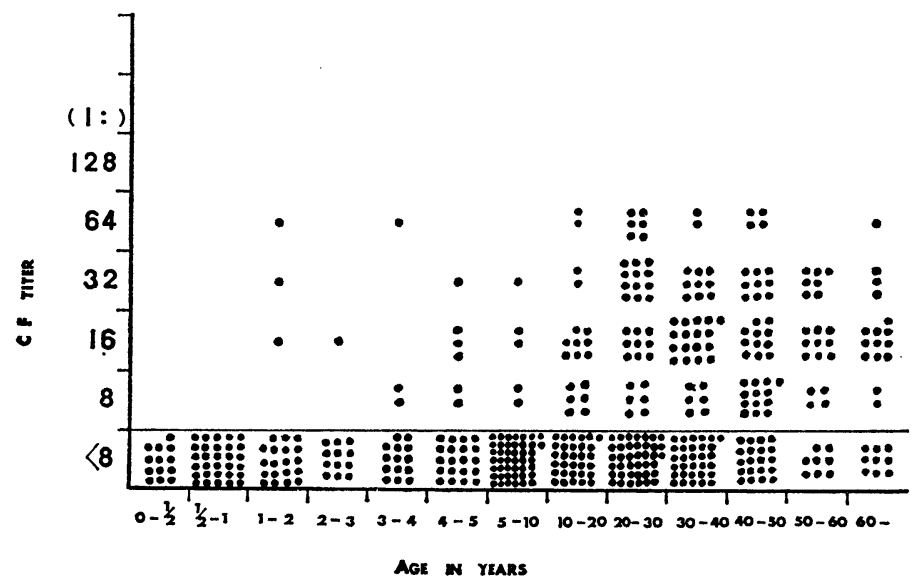

Fig. 2. Age distribution of complement-fixing (CF) antibody against herpes simplex virus among normal individuals.

ution, the majority being higher than 1:80. In the case of complement-fixing antibody, a similar trend as seen above was observed, but the difference between the group of 20-30 years and older groups was not clear, presumably because of overall low titers of antibody due to the relatively low sensitivity of the test.

\section{Comparison of Positive Ratios of the Age Groups}

A clearer delineation of the antibody increase with age was possible when the above data were replotted in terms of the positive ratios. In this analysis, the positive ratio was expressed in two ways. One represents the whole positive sera, while the other only sera showing relatively high titers. The results with neutralizing and complement-fixing antibodies are recorded in Figs. 3 and 4, respectively. It is evident 


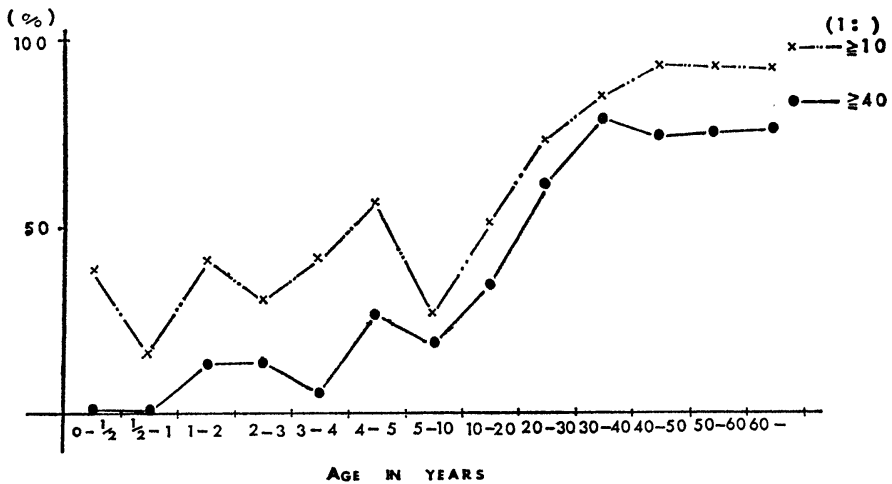

Fig. 3. Age difference of the positive ratio of NT antibody.

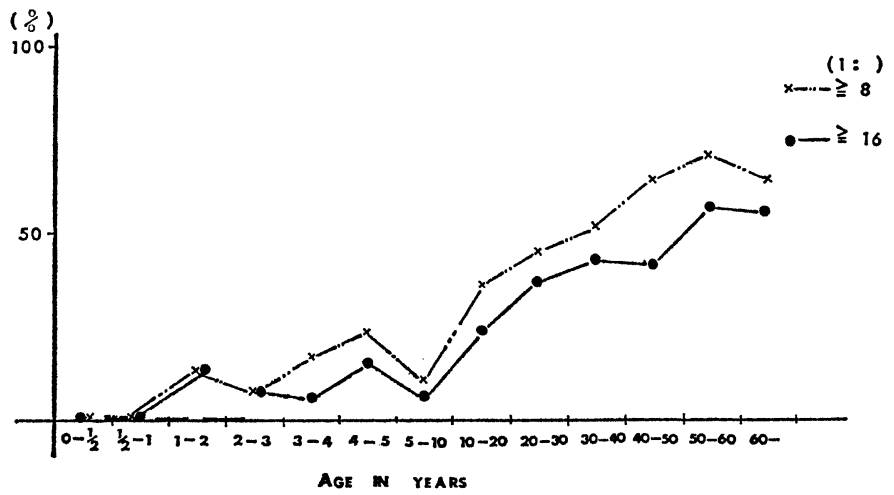

Fig. 4. Age difference of the positive ratio of CF antibody.

that the critical age at which the antibody increase began was 10 years, and the increase continued up to the age of 30 years, when a maximum positive ratio was reached.

\section{Relationship between Neutralizing (NT) and Complement-Fixing (CF) Antibodies}

Sera of each age group were further analyzed for the relationship between NT and $\mathrm{CF}$ antibodies. Since the sensitivity of test differed between the two antibodies, a geometric mean of positive titers was first calculated for each antibody. In Fig. 5, in which the NT titers are plotted against the CF titers, a point representing the above geometric means of both antibodies and an equivalence line passing this point is shown for each age group.

Both the groups of $0-10$ and 10-20 years showed an even distribution of plots around the equivalence line, which may indicate a good parallelism between the two antibodies. In contrast, the three groups older than 30 years obviously showed an uneven distribution, the majority being located under the line. The pattern of the group of 20-30 years appeared to be similar to those of the younger age groups. 


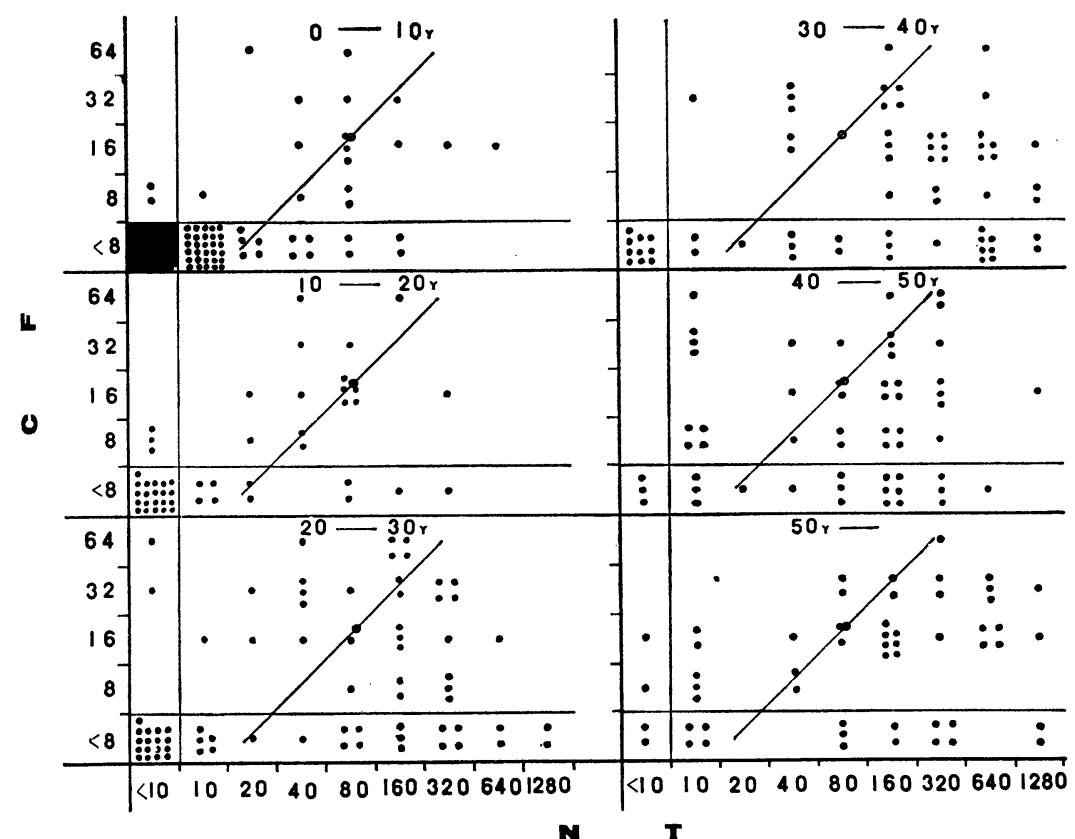

Fig. 5. Correlationships between NT and CF antibody titers in various age groups.

\section{Further Confirmation of the Change in Antibody Distribution}

The change in antibody distribution in the age group of 20 to 30 years occurring during the past decade was further analyzed by replotting the titers of neutralizing antibody against yearly graded ages in Fig. 6. The data of the sera of 1959

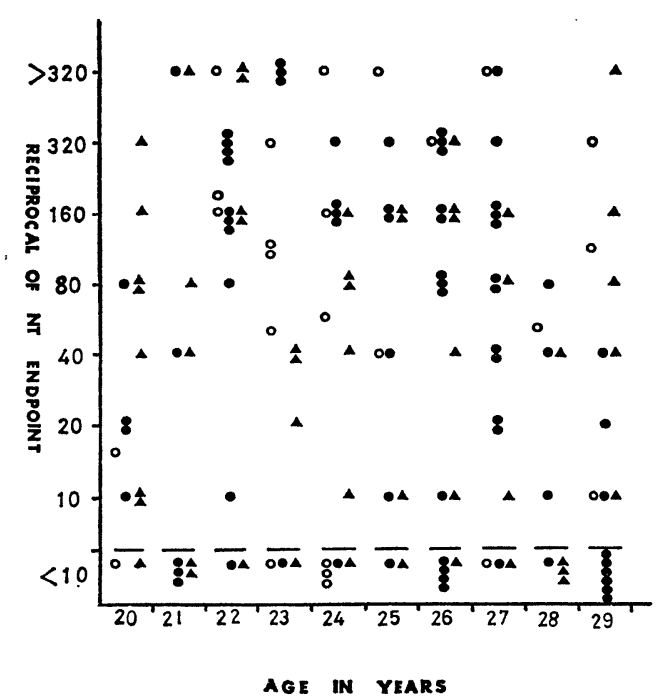

Fig. 6. Comparison of NT titers of sera of persons aged 20 to 30 years collected in 1959 (O), 1969 (O) and 1973 (A). 
were derived from Dr. Yoshino's protocols of the earlier survey. In addition, 51 sera collected in 1973 from normal adults were tested for anti-herpes neutralizing antibody and results are included in this figure. It seems evident that the sera of 1969 as well as those of 1973 covered a wider range of titers than the sera of 1959 .

Percentages of sera showing negative titers and geometric means of positive titers were calculated separately for each survey and presented in Table I. When persons aged 20 to 30 years were totaled, the percentages of negatives were similar but the geometric means revealed gradual decreases from 1959 to 1973 . When persons aged 25 to 30 years were selected, the sera presently examined showed higher percentages of negatives than those of the earlier survey and the geometric means of antibody titers also showed a decreasing trend.

TABLE I

Comparison of neutralizing antibody titers of the age group of 20 to 30 years in 1959,1969 and 1973

\begin{tabular}{|c|c|c|c|c|}
\hline \multirow[b]{2}{*}{ Year } & \multicolumn{2}{|c|}{ Persons aged $20-30$ years } & \multicolumn{2}{|c|}{ Persons aged $25-30$ years } \\
\hline & Negatives $(\%)$ & $\begin{array}{l}\text { Geometric } \\
\text { mean of } \\
\text { positives* }\end{array}$ & Negatives $(\%)$ & $\begin{array}{l}\text { Geometric } \\
\text { mean of } \\
\text { positives* }\end{array}$ \\
\hline 1959 & 24 & $1: 116$ & 11 & $1: 112$ \\
\hline 1969 & 26 & $1: 91$ & 30 & 1: 72 \\
\hline 1973 & 24 & $1: 68$ & 26 & $1: 65$ \\
\hline
\end{tabular}

* In the calculation of geometric mean, titers higher than $1: 320$ were taken as being $1: 320$.

TABLE II

Neutralization tests with a hyperimmune rabbit serum using two different methods

\begin{tabular}{lllllll}
\hline Method & \multicolumn{5}{c}{ Reciprocal of endpoint } \\
\hline $\begin{array}{l}\text { Agar cover slip } \\
\text { inoculation on chick }\end{array}$ & ( I ) & 640, & 640, & 1280, & 1280, & 1280 \\
embryo cells & (II) & 640, & 640, & 640, & 1280, & 1280 \\
\hline One-day egg inoculation against & & & & \\
110 OIU* & 450 & & \\
56 " & 640 \\
28 " & 780 \\
\hline
\end{tabular}

* One-day egg infective units of HF strain of herpes virus.

This comparison of data would have been improper, if the methods used earlier and in the present study had differed greatly in sensitivity. Therefore, a hyperimmune rabbit serum was tested for neutralizing antibody by the two methods. As can be seen in Table II, the titers obtained by the method presently used were 1:640 to $1: 1,280$ in two tests performed in quintuplicate, while the one-day egg inoculation method employed in the earlier survey of Yoshino et al. (1962) gave endpoints of 1:450 to 1:780 depending on the virus amount used. Thus, it was proved that the two methods of the neutralization test gave almost identical endpoints justifying the 
above comparison between the earlier and the present surveys.

\section{DISCUSSION}

Earlier investigations (Tateno et al., 1958; Yamaguchi, 1959a,b; Yoshino et al., 1962) depicted the age distribution of anti-herpes antibodies among general population in this country. However, more than 10 years have elapsed since the last largescale survey performed by Yoshino et al. (1962), and it was thought necessary to reexamine the antibody distribution pattern in order to see whether and to what extent it has changed during the past decade, because the antibody distribution may depend upon socioeconomical standard (Scott et al., 1952), density of population (Anderson and Hamilton, 1949) and sanitary conditions (Dascomb, Adair and Rogers, 1955). This impetus prompted the author to conduct this investigation.

The present results have indicated that normal individuals aged 20 to 30 years possess various levels of neutralizing antibody, not following the all-or-none type of distribution (Burnet and Williams, 1939). Analysis of the NT:CF antibody ratios also indicated that freshly acquired antibodies are frequent among this age group. These features obviously differ from the earlier survey of Yoshino et al. (1962), which disclosed similar features in the age group of 10 to 20 years. That the difference from their data was not due to the use of a different method of the neutralization test was established by comparison of the sensitivities of the two methods. The sera representing this age group in Yoshino et al.'s study (1962) were those of personnel of the National Institute of Health, Tokyo, and the sera of 1973 herein described were taken from nurses and other personnel working in nearby hospitals. Thus there seems to be no difference between these two populations in socioeconomical or any other condition. Nevertheless, significant differences were noted in the geometric mean of antibody titers and also in the percentage of negatives among those aged 25 to 30 years. Hence, it may be valid that antibody distribution of the youngster type has extended coverage of age range during the past years.

This implies that primary and repeated infections among adults may not be so rare as used to be in former days. It is important in this connection that herpetic infection dose not result in milder diseases in adults than in children but does sometimes cause serious diseases such as encephalitis (Zarafonetis et al., 1944; Leider et al., 1965; Overgaard, Hvid-Hansen and Laursen, 1971), generalization (Söltz-Szöts and Fanta, 1971) or Kaposi's varicelliform eruption (Carney et al., 1973), sometimes of a recurrent form (Boake, 1951; Mailman, Miranda and Spock, 1964). In fact, recent reports on the incidence of herpetic encephalitis (Miller and Ross, 1968; Rappel, 1972; Ross, 1972; Sarubbi et al., 1973), herpetic whitlow (Brightman and Guggenheimer, 1970; Orkin, 1970; Juel-Jensen, 1971; LaRossa and Hamilton, 1971), skin infection among wrestlers (Dyke et al., 1965; Porter and Baughman, 1965; Wheeler and Cabaniss, 1965), adult stomatitis (Davies and Longson, 1970), upper (Sheridan and Hermann, 1971) and lower respiratory infections (Douglas et al., 1969; Nash and Foley, 1970; Nash, 1972) and genital herpes (Ng, Reagan and Yen, 1970; Potts, 1970; Wolinska and Melamed, 1970) all indicate that adults are now becoming new targets for herpetic infection.

In this country, too, some reports have appeared on serious or hitherto unusual manifestations of herpetic infection among adults (Shoji, Aoyama and Ogiwara, 1970; 
Shoji and Hondo, 1971; Shoji, 1973; Kawana, Shinkai and Yoshino, 1974). It can be expected, on the basis of the present investigation, that primary herpetic infection of adults causing unusual disease manifestations will become less uncommon in the future. Therefore, watch should be kept for such infections among adults, especially of uncommon types thus far unrecognized.

\section{ACKNOWLEDGEMENTS}

The author is greatly indebted to Dr. K. Yoshino for his excellent guidance and also to the members of Department of Virology of this Institute for their cooperation in performance of the present investigation.

\section{REFERENCES}

ANDERson, S. G. AND HAMilton, J. (1949): The epidemiology of primary herpes simplex infection. Med. J. Australia, 1, 308-311.

BoAKE, W. C. (1951): Recurrent Kaposi's varicelliform eruption. Lancet, 1, 383-384.

BRIGHTMAN, V. J. and Guggenheimer, J. G. (1970): Herpetic paronychia-primary herpes simplex infection of the finger. J. Am. Dental. Assoc., 80, 112-115.

BurNet, F. M. AND Williams, S. V. (1939): Herpes simplex: A new point of view. Med. J. Australia, 1, 637-642.

BURnET, F. M. (1954): Cited in Scott, T. F. McN.: Infection with the virus of herpes simplex. New Engl. J. Med., 250, 183-188.

Carney, J. F., Caroline, N. L., Nankervis, G. A. And Pomeranz, J. R. (1973): Eczema vaccinatum and eczema herpeticum in Darier disease. Arch. Dermatol., 107, 613-614.

DAscomb, H. E., AdAIR, G. V. AND RogGERS, N. (1955): Serologic investigations of herpes simplex virus infections. J. Lab. Clin. Med., 46, 1-11.

DAviEs, R. M. AND Longson, M. (1970): Herpetic infection in adults. Oral Med., 30, 41-47.

Douglas, R. G., Anderson, M. S., Weg, J. G., Wiliams, T., Jenkins, D. E., Knight, V. AND BeAll, A. C. (1969): Herpes simplex virus pneumonia. J. Am. Med. Assoc., 210, 902-904.

Dyke, L. M., Merikangos, U. R., Bruton, O. C., Trask, S. G. and Hetrick, F. M. (1965): Skin infection in wrestlers due to herpes simplex virus. J. Am. Med. Assoc., 194, 1001-1002.

HoNDO, R. AND Yoshino, K. (1972): Further simplification of the serum neutralization test with herpes simplex virus. Japan. J. Microbiol., 16, 321-327.

JuEl-Jensen, B. E. (1971): Herpetic whitlow: a medical risk. Brit. Med. J., 4, 681.

KAWANA, T., ShinkAI, K. AND Yoshino, K. (1974): Typing of herpes simplex virus strains of genital and nongenital origins. Japan. J. Microbiol., 18, 235-241.

LA Rossa, D. And Hamilton, R. (1971): Herpes simplex infection of the digits. Arch. Surg., 102, 600-603.

Leider, W., MAgoffin, R. L., Lennette, E. H. And Leonards, L. N. R. (1965): Herpessimplex virus encephalitis; its possible association with reactivated latent infection. New Engl. J. Med., 273, 341-347.

MAIlMAN, C. J., MiRANDA, J. L. AND Spock, A. (1964): Recurrent eczema herpeticum. Arch. Dermatol., 89, 815-818.

Miller, J. D. AND Ross, C. A. C. (1968): Encephalitis - a four-year survey. Lancet, 1, 1121-1126.

NASH, G. AND FolEY, F. D. (1970): Herpetic infection of the middle and lower respiratory tract. Am. J. Clin. Pathol., 50, 857-863. 
NASH, G. (1972): Necrotizing tracheobronchitis and bronchopneumonia consistent with herpetic infection. Human Pathol., 3, 283-291.

NG, A. B. P., Reagan, J. W. AND YeN, S. S. C. (1970): Herpes genitalis: Clinical and cytopathologic experience with 256 patients. Obstet. Gynecol., 36, 645-651.

ORKIN, F. K. (1970): Herpetic whitlow - occupational hazard to the anesthesiologist. Anesthesiology, 33, 671-673.

OvergaARD, J., Hvid-Hansen, O. AND LAursen, B. (1971): Acute necrotizing encephalitis caused by herpes simplex virus. Dan. Med. Bull., 18, 18-24.

Porter, P. S. AND Baughman, R. D. (1965): Epidemiology of herpes simplex among wrestlers. J. Am. Med. Assoc., 194, 998-1000.

Potts, I. F. (1970): The increase in venereal disease. Med. J. Australia, 2, 1149.

RAPPEL, M. (1972): Herpes encephalitis revisited. Brit. Med. J., 2, 655-656.

Ross, C. A. C. (1972): Herpes simplex and temporal lobe epilepsy. Brit. Med. J., 3, 112.

Sarubbi, F. A. JR., Sparling, P. F., Glenzen, W. P. AND Hill, C. (1973): Herpes virus hominis encephalitis. Virus isolation from brain biopsy in seven patients and results of therapy. Acta Neurol., 29, 268-273.

Scott, T. F. MCN., Coriell, L., Blank, H. AND Burgoon, C. F. (1952): Some coments on herpetic infection in children with special emphasis on unusual clinical manifestations. J. Pediat., 41, 835-843.

SHERIDAN, P. J. AND HERMANN, E. C., JR. (1971): Intraoral lesions of adults associated with herpes simplex virus. Oral Surg. Oral Med. Oral Pathol., 32, 390-397.

Shoji, H., Aoyama, Y. AND OGIwARA, H. (1970): An autopsy case of herpes simplex encephalitis with virus isolation. Clin. Neurol., 10, 281-285 (in Japanese).

ShoJI, H. AND Hondo, R. (1971): Two suspected adult cases of mumps and herpes simplex virus meningitis. "No to Shinkei", 23, 85-89 (in Japanese),

SHoJi, H. (1973): Clinical features of herpes simplex encephalitis. Clin. Neurol., 13, 491498 (in Japanese).

Söltz-Szöts, J. AND FANTA, D. (1971): Generalisierter herpes simplex beim Erwachsenen. Hautarzt, 22, 215-217.

Tateno, I., Yokoyama, T., Suzuki, S., Sugiura, A. And Fukaya, I. (1958): Age distribution of the neutralizing antibody to herpes simplex virus. Japan. J. Exptl. Med., 28, 375-380.

WheEler, C. E. AND CABANISS, W. H. (1965): Epidemic cutaneous herpes simplex in wrestlers. J. Am. Med. Assoc., 194, 993-997.

Wolinska, W. H. AND MElamed, M. R. (1970): Herpes genitalis in women attending Planned Parenthood of New York City. Acta Cytol., 14, 239-242.

YAMAGUCHI, S. (1959a): Serological-epidemiological studies of herpes simplex. I. Frequency distributions of complement-fixing antibody for herpes simplex virus in human populations of various years of age. Nihon Eiseigaku Zasshi, 13, 842-847 (in Japanese).

YAMAGUCHI, S. (1959b): Serological-epidemiological studies of herpes simplex. II. On the frequency distributions of virus-neutralizing antibody and on the relations between the virusneutralizing and complement-fixing antibodies. Nihon Eiseigaku Zasshi, 13, 848-853 (in Japanese).

Yoshino, K., Taniguchi, S., Furuse, R., Nojima, T., Fujil, R., Minamitani, M., TADA, R. AND KUBotA, H. (1962): A serological survey for antibodies against herpes simplex virus with special reference to comparatively heat-labile complement-fixing antibodies. Japan. J. Med. Sci. Biol., 15, 235-247.

Zarafonetis, C. J. D., SAmdel, J. E., AdAms, J. W. And Haymaker, W. (1944): Fatal herpes simplex encephalitis in man. Am. J. Pathol., 20, 429-441. 